\title{
Practice and Exploration of the "3231" Education System for the Second Classroom of Jilin Institute of Chemical Technology
}

\author{
Yuchi Xie \\ Jilin Institute of Chemical Technology \\ JiLin, China
}

\begin{abstract}
Education Cultivation Project (abbreviated as "3231") is a talent training engineering system that is suitable for the development of the second class of Jilin Institute of Chemical Technology. There are obvious achievements in ideological and political education work, the work of the Youth League, the work of the education of students, the construction of students' cadres and the construction of campus cultural activities of Jilin Institute of Chemical Technology. This paper mainly discusses the practice of "3231" education engineering system, which can provide effective direction for the development of college students in Jilin Province.
\end{abstract}

Keywords_Jilin Institute of Chemical Technology; "3231"; Education System

\section{INTRODUCTION}

The "3231" obtained by our university in practice is in line with the central spirit and the systematic theory of the task of talent training in local colleges and universities, which provides a new way of thinking for local colleges and universities to face talent training. This paper summarizes "3231" theoretically and puts forward some innovative suggestions.

\section{ThE "3231" EdUCATION SySTEM IS A SOLID}

FOUNDATION AND GUIDE NAVIGATION AIDS IN OUR SCHOOL

The"3231" education and training system is established on the basis of the campus cultural activities of the three sections and two sessions, that is, the" 32 "in the" 3231 ", the three sections are the College Students' Science and Technology Festival, the College Students' Language and Art Festival and the College Students' Association Culture Festival; the two sessions are the "Welcome to the Students' Party" and the "Welcome to the New Year's Celebration Party "; the" 31 "refers to an organization:" Youth Volunteer Work Station "; an idea: the "Life-oriented" moral education concept and a system: the "National Evaluation and Evaluation System" composed of the "Quality Assessment System ", which is up to the standards of the League branch. This is our school's Communist Youth League after years of practice summed up the theory of experience, but also in practice is growing up a new way of thinking.

A. The educational training system supports the basic framework of talent training in our school.

Jintao $\mathrm{Hu}$ proposed: "We will promote sound and rapid economic and social development, to realize the great rejuvenation of the Chinese nation. Technology is the key, talent is the core, and education is the foundation. As an important combination of science and technology first productivity and talent first resource, higher education plays a very important role in national development. In order to improve the quality of higher education in an all-round way, we must vigorously improve the level of personnel training. The fundamental task of higher education is personnel training."'[1]In recent years, the large-scale enrollment expansion of colleges and universities has made the number of college students growing continuously. The sharp increase in the number of college students has put forward higher requirements for the work of talents in Colleges. This paper puts forward a more serious task for the ideological and political education and the construction of the student cadre team, which are the key links of cultivating talents in Colleges. It is based on the adaptation to this new situation that the "3231" talent training project, which gives students and cadres a broad space for development, has been established. As a special group concerned by higher education workers in recent years, how to train student cadres efficiently and on a large scale has become a topic that can not be ignored. With the coming of information age, cooperation and competition have become the mainstream of the times. Therefore, for both sides of cooperation, how to cooperate is not only a matter of professional knowledge, but also a matter of humanistic quality, practical ability, cooperation ability, problem-solving ability, adaptability, organizational management ability, self-control ability, professionalism, etc.[2]As a practical product of the student organization in Jilin Institute of Chemical Engineering in the construction of student cadres, 3231 enables the student cadres to complete the growth cycle of self-recognition, selfdevelopment and self-improvement on the platform by means of various combination of experience, characteristics positioning and concrete practice. At the same time, we should specialize in our functions, strengthen our specialties and make up for the shortcomings so as to enhance the ability of student cadres in an all-round way. At the same time, the platform's large-scale, brand and team characteristics have also strengthened the sense of cooperation, service and cohesion within the student cadres and even all the students. It has played a very good guiding role in improving the cohesion of our school and promoting the common progress of our students Therefore, "3231" talent training project supports the basic framework of our school's talent training. 
oriented morality, morality and morality" is that it fully realizes the care and education for students. Their life world is the practice subject of moral education, so that moral education can be settled down. Under the background of profound social changes in our country, we should pay attention to the actual needs and development of students, and effectively improve the effectiveness, pertinence and universality of moral education.

\section{III. "3231" TALENT PROMOTION PROJECT INTEGRATES CAMPUS CULTURE AND IDEOLOGICAL AND POLITICAL EDUCATION AND CREATES A NEW SITUATION OF MUTUAL PROMOTION.}

"Campus culture" refers to the way and result of activities in the process of school education, learning, life and management with the school campus as the geographical environment, social culture as the background, school administrators and all teachers and students as the main body. Campus culture is an important part of campus culture. It is the embodiment of campus values shared by every member of college life and these values in material, behavior and spirit. It reflects the overall spiritual outlook, school running policy, education and management level of colleges and universities, the overall ideological and moral quality, psychological quality of teachers and students and the general working, learning and living conditions, as well as the basic quality requirements of each member of the school.[4]

\section{A. The three sections and two sessions of "3231" campus activities speed up the process of campus culture construction.}

The campus culture of the university includes many subjective and objective factors, such as life, entertainment, learning and so on. The main body of campus activities of the three sessions and two sessions has realized the benign transition from campus activities to campus culture inheritance. The three festivals are "College Students' science and the technology festival, language and Art Festival, and Community Culture Festival"; the two conferences are "welcome students on July 1" and "welcome new students to celebrate National Day".

The purpose of "university students' science and Technology Festival" is to promote the atmosphere of science and technology culture on campus and arouse the interest of the whole school students to actively participate in scientific research. Through the university students' science and technology festival to help the campus science and technology innovation, enhance the enthusiasm and initiative of students to participate in extracurricular science and technology activities; organize students to participate in the national and provincial "Challenge Cup" competition activities, and further cultivate students' innovation spirit. To standardize the management of extracurricular scientific and technological activity groups, encourage and support students to establish various extracurricular scientific and groups of the technological activity according to their interests and hobbies, increase the support for students' extracurricular scientific and technological activity groups, hire famous teachers of the school for correct guidance, and provide high-quality services for students' research-based learning. At present, with the strong 
cooperation of the Youth League Committee of each teaching college, 282 science and technology activity groups with high academic levels covering all disciplines have been established, making them an important driving force for students to actively participate in science and technology activities.

In the gradual exploration and practice, the "Language Art Festival" has formed a mode of "sponsored by the school Youth League Committee, undertaken by the sub-Youth League Committee, jointly run and manages each other". Many years' practice shows that the language art festival has a significant effect on improving the humanistic quality of students in our school, exploring talents with language talent, and enriching students' after-school cultural life. At the same time, the significance of the language art festival is far beyond exploring talents and activating campus culture. Another important significance of it is that it is the direction of guiding campus culture.

"Club Culture Festival" is the most popular and influential club culture feast in our school. As the most important position of cultural communication in Colleges and universities, student associations can realize the diversity and innovation of campus culture. As a platform for the school's Youth League Committee to provide mutual exchange and attract students from the school to participate in, the community culture festival has successfully strengthened the links between the community and the community, the community and the students. It promotes the healthy development of the community and creates a rich campus culture atmosphere; helps the overall improvement of students' personal quality, builds a platform for the development of students' personality, and meets the diversified needs of students for quality improvement; and plays an active and effective role in promoting the campus culture construction of the school.

The Party of "welcoming students on July 1" and the Party of "welcoming new students on National Day" are the two largest parties designed by "3231" for students, and also the biggest stage for students to show their own style. Welcoming new students and seeing off old students reflect the school's concern for new students and old students, and the large-scale party held on July 1 and the national day is to achieve the purpose of education of students' patriotism. Patriotism education is not only the key content of cultivating the mainstream ideology of college students at this stage, but also the necessary path to cultivate the successors of the socialist cause. Contemporary college students grow up in the new situation of reform and opening up, and the way of expressing patriotism is more direct and strong. However, there are still some phenomena, such as the inability to internalize the connotation of patriotism in the heart, and the difficulty to form their own unique opinions. The Party of "welcoming students on July 1" and the Party of "welcoming new students on National Day" are performed by students and guided by teachers, from the stage performance form to the details of the movement of the ideas and emotions transmitted by careful scrutiny. It can better promote students' understanding of patriotism and integrate their understanding into the stage display, trying to better combine with the performance of the program, in this way, we can continuously output positive energy.

\section{B. "3231" is a practical exploration in the current educational environment.}

Today, with the increasingly rich social information, the information-based network platform puts forward new challenges to the traditional campus culture, and also puts forward new requirements to the ideological and political education in Colleges and universities. In September 2004, the opinions of the CPC Central Committee and the State Council on Further Strengthening and improving the ideological and political education of college students stress that "with the education of ideas and beliefs as the core, with the education of patriotism as the focus, with the construction of ideology and morality as the basis, with the overall development of college students as the goal, emancipate the mind, seek truth from facts, keep pace with the times, adhere to the principle of peopleoriented, close to reality, close to life,close to students, strive to improve the pertinence, effectiveness, attraction and appeal of Ideological and political education, and cultivate qualified builders and reliable successors of socialism with all-round development of morality, intelligence, physical education and beauty. "[5]

Ideal and belief education, patriotism education and ideological and moral construction all have concrete practice in "3231". At the same time, in the design of "3231", the paper systematically distinguishes and reasonably avoids the places that are easy to be confused and misunderstood in the ideological and political education work in Colleges and universities, to make them more suitable for the specific situation of the school. Therefore, the "3231" which grows up and matures in the era is the concentrated embodiment of the continuous development and innovation of the ideological and political education work and the campus culture construction of Jilin University of chemical technology.

\section{CONCLUSION}

Modern universities should cultivate talents with reasonable knowledge structure, strong practical ability, high comprehensive quality, comprehensive development and sustainable development. In the Chinese society in the social transition period, the lifestyle and attitude of college students are more and more diversified, and it is more and more important to explore the systematic talent training program which accords with the background of the times and the law of students' growth. The "3231" talent training project has farreaching significance for local colleges and universities to cultivate students' comprehensive quality, form complete values, construct multi - knowledge structure and guide students to develop a healthy lifestyle.

\section{REFERENCES}

[1] Jintao Hu. An important speech at the centennial celebration of Tsinghua University[EB/QL].http://www.bj.xinhuanet.com/bjpd_sdzx/201104/25/content_22604972.htm. 2011, 4 (In Chinese)

[2] Dan Ding, Zhihua Wang. On the second classroom education mode in Colleges and Universities.[J]Journal of Hunan University of Science and Engineering, 2008, 02.(In Chinese)

[3] Ao Wang. Research on the method of moral education in Colleges and Universities[D].Sun Yat-sen University, SYSU, 2010, 06.(In Chinese) 


\section{PRESS}

[4] Guizhen Zhou, Qingmin Li. On the construction of the harmonious campus in Colleges and Universities[J].Shandong University Press, 2008:147.(In Chinese)

[6] Ying Liu, Guangjun Gao. The reform and strategy of talent training mode in Colleges and Universities.[J]Successful Road, 2015, 06.(In Chinese)

[5] The Central Committee of the Communist Party of China. The State Council.[Z].[2004]16.(In Chinese) 